\title{
The Poetics of (In)visibility: A Stylistic Analysis of Caryl Phillips' Foreigners: Three English Lives Daria Tunca
}

Abstract: Caryl Phillips' multi-voiced texts have often been studied through the lens of Bakhtinian polyphony. In this essay, I focus on the volume of fictionalized biographies Foreigners: Three English Lives (2007) to demonstrate that polyphony in Phillips' work resides not only in the structural confrontation of characters' and narrators' voices but also in the subtle inscription of the implied author's subjectivity within his texts. Borrowing methods from the discipline of stylistics, I first establish through a focus on the use of adjectives and modality (that is, grammatical means indicating how speakers position themselves in relation to propositions) in the opening section of Foreigners, "Dr Johnson's Watch," how the first-person narrator gradually transitions from tentativeness to self-confidence. This change enables the implied author, on the one hand, to expose the thwarted logic of the colonially tinted discourse of his eighteenth-century narrator and, on the other, to reflect on the process of ideological encoding inherent in the writing of historiography. Such an investigation based on modality further allows me to challenge the critical consensus that the second section of the book, "Made in Wales," is a straightforward factual account. I suggest that the story of the rise and fall of mixed-race boxer Randolph Turpin is in fact a highly polyphonic narrative that features increasingly marked clashes in modality and point of view. These clashes, I argue, draw attention to the construction of historiographical discourse deceptively made to appear so commonsense by the narrator of "Dr Johnson’s Watch." 
Keywords: Caryl Phillips, Foreigners, Bakhtin, polyphony, stylistics, modality

The problem with every story is not the story, it's how to tell the story.

$$
\begin{aligned}
& \text { Caryl Phillips qtd. in John McLeod, } \\
& \text { "'Who are you calling a foreigner?"” (288) }
\end{aligned}
$$

"But what is it?" Thus Evelyn O'Callaghan reports the words of the historian she consulted while doing research on Caryl Phillips' novel Cambridge (1991), a narrative O'Callaghan describes as "a hybrid, syncretic fabrication" (40) that largely relies on a "pastiche" of historical travel journals (36). Similarly puzzled reactions have greeted the publication of Phillips' Foreigners: Three English Lives (2007), a book said to be "generically unpindownable, midway between an essay and a novel" (Ledent, "Determinism" 84), which imaginatively retraces the lives of three black men who lived in England between the eighteenth and the twentieth centuries: Samuel Johnson's Jamaican servant Francis Barber, the mixed-race boxer Randolph Turpin, and the Nigerian immigrant David Oluwale.

For the seasoned reader of Phillips' work, however, any sense of bewilderment over the generic ambiguity of Foreigners is likely associated with a paradoxical feeling of recognition because a blurring of boundaries between the realms of fiction and non-fiction as well as a combination of different genres under the same cover are some of the writer's most conspicuous trademarks. Cambridge is an early example; a later text worthy of note is Dancing in the Dark (2005), a novel that reconstructs the life of vaudeville artiste Bert Williams, alternating between imagined recreations of the protagonist's introspective moments and real archival material, including song lyrics and newspaper reports. Interestingly, even Phillips' novels that are regarded as purely fictional often bear traces of non-fictional texts-for example, the author alludes to Anne Frank's diary in Higher Ground (1989) and The Nature of Blood (1997) and adapts excerpts from Olaudah Equiano's Interesting Narrative across $A$ Distant Shore (2003). ${ }^{1}$ 
The variety of sources Phillips uses in his novels is but one element that testifies to his reliance on polyphony, a concept Mikhail Bakhtin defines as "[a] plurality of independent and unmerged voices and consciousnesses" co-existing within a single text (Poetics 6; emphasis in original). "The polyphonic novel," Bakhtin continues, "is dialogic through and through. Dialogic relationships exist among all elements of novelistic structure; that is, they are juxtaposed contrapuntally" (40; emphasis in original). Considering the accuracy with which Bakhtin's words describe Phillips' writing technique, it comes as no surprise that the Russian scholar's theory has repeatedly inspired critics of the British-Caribbean author's work over the years. As early as 1992, Bénédicte Ledent identified the "dialogic multi-voicedness" of Cambridge ("Voyages" 54), a point that she also developed in relation to Crossing the River (1993) on two separate occasions in the following years ("Remembering Slavery," "Vocal Kaleidoscopes"). In these three essays, Ledent emphasizes the dialogic potential of Phillips' polyphonic constructions, that is, how the "diverging voices" found in his texts "interact ... with one another to produce meaning(s)" ("Vocal Kaleidoscopes" 285). Ledent distinguishes between a form of "'outer' dialogism," created by the inclusion of voices from other texts in Phillips' own, and a type of "inner dialogism" ("Vocal Kaleidoscopes" 288) resulting from the juxtaposition, within single novels, of "narrative viewpoints which complete and contradict each other in a crisscrossing dialogue" ("Remembering Slavery" 277). As Ledent's analyses suggest, the clashes and contradictions in Phillips' texts reveal that his works exploit Bakhtinian polyphony in its full complexity, for the writer does not simply feature seemingly diverse voices only to subordinate them to a single, easily circumscribable, authorial viewpoint; rather, the multiple characters and focalizers found in his books generate nuanced, sometimes conflicting, interpretations of history. Lars Eckstein also suggests that Phillips makes an elaborate use of polyphony: in his analysis of Cambridge, he observes that the speech of the white English narrator, Emily, "dialogically confronts, on equals terms, the ideologies of the older texts it writes back to" (82) and that her narrative is, moreover, "juxtaposed dialogically" with that of the slave Cambridge (85). Ledent's and Eckstein's studies are among the 
most incisive investigations into the dialogic aspects of Phillips' fiction. Other research on the writer's oeuvre presents similar assertions to theirs, with various degrees of detail and different emphases; in fact, critics have analyzed the dialogic aspects of Phillips' texts in such depth that, nowadays, the highly polyphonic nature of his works can be regarded as a premise rather than a hypothesis.

Remarkably, within the "many-tongued chorus" of voices (Phillips, Crossing the River 1, 237) that infuses Phillips' writing, the author's own voice is notably absent. Phillips has repeatedly commented on this perceived self-effacement in interviews, stating, for example: " $P \mathrm{~m}$ not present. The characters are totally in the fore. I'm invisible... I hide behind the characters" (Yelin, "Interview" 51; emphasis in original). In what follows, I argue that Phillips hides not only behind his characters but also within his own texts, a suggestion that I develop with reference to Foreigners. Admittedly, as Phillips' use of the word "character" in the excerpt from his interview with Louise Yelin indicates, his comments about invisibility in fact relate specifically to his fiction, whereas in non-fiction, he says, "I always feel that I have to be more present as an agent of narrative purpose" (Phillips in Ledent, “'Only Connect” 190). This statement certainly applies to the travelogues The European Tribe (1987) and The Atlantic Sound (2000) and to the collections of essays A New World Order (2001) and Colour Me English (2011). However, the question of (in)visibility is far less easy to settle in the case of the generically liminal Foreigners, in which "a voice which is most probably [Phillips'] emerges in the second and third sections" of the book but is said to be absent from the first (Ledent, "Only Connect" 190). While it is important for the sake of methodological accuracy to be aware of the correlation between fiction and authorial invisibility on the one hand, and non-fiction and authorial visibility on the other, these differences will matter little to my argument. My suggestion that Phillips hides within his works is not so much linked to the presence or absence of a speaking "I" that bears resemblance to the real-life writer as to the ways in which "Phillips," as the implied author (that is, as the "governing consciousness of the work" [Rimmon-Kenan 87]), discreetly, but nonetheless perceptibly, shapes the sometimes slippery 
and elusive meanings of his texts by setting up polyphonic resonances within them.

Interestingly, despite Phillips' claim to absence and invisibility in his fiction, much of the existing criticism treats the writer as a presence hovering above his own works, be they fictional or not. On several occasions, critics have used the metaphor of "orchestration" to describe this authorial role, an image that echoes Bakhtin's own musical metaphor of polyphony. For example, in relation to Crossing the River, Ledent observes that the writer, without being present himself in the text, "orchestrate[s] all the individual voices . . . that his novel contains" ("Vocal Kaleidoscopes" 287). In her discussion of Foreigners, Yelin suggests that the author "collects and orchestrates (or invents in some cases)" the material that constitutes the section on David Oluwale ("Plural Selves" 69). Similar ideas implicitly run through many studies of Phillips' work, particularly those that, like Ledent's, concentrate on how the implied author covertly criticizes racist or sexist ideologies, for instance by lending his characters statements replete with euphemisms and ironies that betray the hypocrisy or contradictions of colonial modes of thought. Conventional hermeneutic techniques have often enabled Phillipsian scholars to uncover the dialogic subtlety of the writer's texts, yet the absence of a linguistic focus in many analyses - that is, these studies' reliance on close reading methods as opposed to more systematic linguistic approaches — has caused occasional slips to occur. For example, in an otherwise compelling article, Yelin highlights "the unselfconscious parroting of racist clichés that drive his [the first-person narrator's] identification of Barber as 'Blacky,' 'Dr. Johnson's negro,' a 'pathetic negro,' and so forth" in the opening section of Foreigners, entitled "Dr Johnson's Watch" ("Migrant Subjects"). Obviously, the terms "blacky" and "negro" are offensive racial designations nowadays, but both were in current use at the time of narration, the turn of the nineteenth century, as a quick dip into the Oxford English Dictionary confirms. ${ }^{2}$ Yelin undoubtedly knows this - the critic's competence is certainly not in question. What might be disputed, however, is her particular strategic choice: she opts for an analytical shortcut that conflates two moments in history, probably with the aim of lending maximum force to her ultimate 
point, which is that Phillips' text denounces the pervasiveness of racist ideologies across centuries. Nevertheless, the casting of "Dr Johnson's Watch" in this particular light seems to rob the narrative of some of its artistic subtlety. More precisely, because Yelin's primary focus is not on form, she entirely leaves aside in her analysis the textual elements that make the opening section of Foreigners a masterpiece of dialogism.

Clearly, it would be both sterile and naive to dismiss Yelin's remark altogether and claim that only historical accuracy is at stake in Phillips' compulsive attributing of the term "negro" to his well-meaning white narrator (the other term discussed by Yelin, "blacky," is used only once, [Phillips, Foreigners 56]). That the narrator is racially prejudiced by contemporary standards, as Yelin points out, is beyond dispute. Yet the full resonance of his use of "negro" cannot emerge unless one considers the term's "socially charged life" (Bakhtin, Dialogic 293). Indeed, it is only by heeding the word's long history that one can determine the subtlety of the articulation between "the direct intention of the character who is speaking, and the refracted intention of the author" more than two centuries later (Bakhtin, Dialogic 324). Put differently, the connotations of the word "negro" in the first section of Foreigners only surface when one juxtaposes the term's socially condoned use in the eighteenth and nineteenth centuries with its racially offensive use at the time when Phillips put pen to paper-all the while taking into account the writer's awareness of this historical discrepancy. From this idea derives the decisive observation that, when analyzing fiction such as Phillips', one must not "hasten to narrow [the] provenance [of words] to the single speaker we call "voice" (Bal 45) but rather view linguistic items as loci of ideological negotiations that have taken place across time (Bakhtin, Dialogic 293-94). Thus, Mirja Kuurola's observation about Phillips' novel Cambridge that "the ventriloquistic recreations of period attitudes, prejudices, and conflicts" partake of "a process of criticism" (132) by the contemporary author can be applied to the linguistic choices made in Foreigners too. In sum, Phillips, in positioning his works at the crossroads where significations-historical and contemporarymay meet and intertwine, is the discursive "orchestrator" described by Ledent and Yelin. However, the writer's use of language also subtly 
refracts his own sensibilities and involvement in the history of words. In this sense, the author's subjectivity is inevitably inscribed inside the text, not on its periphery-hence the suggestion that Phillips hides within his works.

While this formulation represents a slight shift from the traditional "orchestrator" metaphor, it must be acknowledged that Phillipsian critics have come close to this idea before. In fact, many scholars seem to have been guided by a very similar notion of authorial involvement in the text when developing their analyses of Phillips' books. The contribution of the above observations, therefore, is not so much epistemological as methodological: my discussion does not necessarily allow one to retrieve otherwise inaccessible forms of knowledge, but it makes a case for increased explicitness in analytical procedures. Such systematic transparency is one of the cornerstones of stylistics, a discipline defined by its practitioners as "an approach to the analysis of (literary) texts using linguistic description" (Short 1; emphasis in original). A stylistic examination of Phillips' writing is bound to offer terminological precision and methodological reflexivity but, importantly, these benefits are not ultimate aims in themselves; rather, they are aids designed to enhance our understanding of the text and its linguistic mechanisms. I demonstrate the latter statement in two different ways in this essay. Firstly, I briefly show how paying attention to a precise textual feature-namely the use of attributive adjectives in "Dr Johnson's Watch" — can help to readjust and develop existing interpretations of the narrative. Secondly, I explore how a stylistic model built around the connections between modality (that is, grammatical means indicating how speakers position themselves in relation to propositions) and point of view can help to shed further light on the narrative strategies developed in the first and second sections of Foreigners. These strategies, which seem radically different at first sight, in fact jointly inform how Phillips uses the genre of "creative biography” (Ledent, “'Only Connect” 188) to offer larger reflections on historiography. In other words, I focus not so much on why the author chose to tell the stories of Barber and Turpin as on why he chose to tell them the way that he did. 
Phillips has been widely praised for the elegance of his prose, yet stylistic analyses of his work are few and far between. This scarcity of scholarly material not only accounts for a series of critical blind spots but also for sheer incomprehension, on the part of some commentators, of the importance of the linguistic makeup of Phillips' texts. For example, in a review of Renée T. Schatteman's Conversations with Caryl Phillips, Jeremy Taylor castigates those interviewers who dare to ask the author about the technical aspects of his craft, accusing them of "want[ing] to simplify and codify the writing process." Among the targets of Taylor's scathing criticism is a passage from Bénédicte Ledent's interview with the writer:

BL: "Dr. Johnson's Watch" contains a lot of adjectives. Was this a deliberate choice? Why?

CP: I try to be very precise with adjectives. (“'Only Connect” 190)

Admittedly, Phillips' answer is not as helpful as one might have hoped but, as it turns out, Ledent's question is particularly astute. "Dr Johnson's Watch" contains a dizzying number of adjectives, which provide an important key to unraveling the section's narrative strategy, as I argue below. If anything, this interview question shows that sharp critical acuity may occasionally need to be complemented by more systematic linguistic procedures, no matter how painstaking or tedious these may appear to be at first. This can perhaps best be illustrated by continuing the discussion on the presence of adjectives in "Dr Johnson's Watch" where Ledent left off.

In her analysis of Foreigners, Ledent observes that "for all his relative open-mindedness, the narrator is blinded by a rigid sense of race and class, which was by no means unusual for the time. This transpires most visibly in his own choice of words - for example, all the racerelated adjectives (such as "sable," "sooty," and "negro" [5-6]) that he uses whenever he speaks of Barber" ("Determinism" 79-80). Eva Ulrike Pirker similarly comments that "the narrator uses an excess of descriptions and attributes pertaining to Barber's blackness" (213). Both critics are right. Like Yelin, who reacts to the term "negro," Ledent and 
Pirker respond to an element that is particularly striking to the reader of Phillips' mock-historical account-even more so, one might argue, to the scholar attuned to the author's interest in race. Ledent's and Pirker's observations rely on the perception of a precise stylistic technique: in "Dr Johnson's Watch," blackness is "overlexicalized"; that is, the "text makes extensive and repetitive use of sets of terms" to refer to Barber's complexion so that the concept of race, and "the ideas [it] symbolize[s], become foregrounded" (Fowler 218-19).

However, this is only part of the story. Rather than merely reading Phillips' text and allowing our literary radar to pick up on foregrounded elements, let us for a moment switch methodologies and pay more systematic attention to the narrator's use of adjectives throughout his account, even when these items appear unremarkable initially. A slightly different picture emerges. For instance, in a passage in which the narrator discusses Francis Barber's time in the navy (Phillips, Foreigners 28-30), the noun phrases containing attributive adjectives (or adjectivelike modifiers) that are used to identify Dr. Johnson's servant include: "sixteen-year-old Francis Barber" (28), "the young negro" (29), "the black boy" (29), "young Francis" (used three times [29]), and "the eighteen-year-old young man” (30). In other words, Barber's youth, like his complexion, is overlexicalized through the use of adjectives and nouns, presumably because his age and inexperience emphasize his vulnerability in the eyes of the anxious Dr. Johnson and perhaps also of the narrator himself.

Even more arresting is another instance in which Phillips makes heavy use of attributive adjectives. When the unnamed narrator, who is preparing a biographical sketch on Barber for a magazine, goes to the Jamaican's house sixteen years after Johnson's death, he is accompanied by an anonymous carriage driver, who makes only a couple of brief appearances in the story and remains a minor figure throughout. This man is successively referred to as "the ancient driver" (Phillips, Foreigners 15, 16), "the wizened man" (16), "the aged driver" (16), "the ancient man" (16), "the decrepit fellow" (17), "the same ancient man as before" (34), and "the impudent elder of Lichfield" (35). All the noun phrases that include attributive adjectives contain a reference to the man's 
advanced age, despite the fact that this quality does not appear to have any obvious relevance to the events in the story; the man's elderliness does not, for example, visibly affect his driving abilities. In short, if, as Ledent and Pirker suggest, the narrator is fixated on Barber's blackness, then he is equally obsessed with the driver's old age. This is all the more noticeable as the attributive adjectives used in relation to the latter character are non-restrictive modifiers: they express a property of the referent but are not used to differentiate, for instance, between the old driver and another younger colleague of his.

This concern with different forms of human categorization is hardly surprising coming from a man who has a "rather inflexible . . . view of the 'natural order' (33) that should preside over society" (Ledent, "Determinism" 80)—a society in which individuals of "superior rank" (Phillips, Foreigners 59), among whom the narrator includes himself, are firmly situated above those of lower racial and social status. But the narrator's insistent use of non-restrictive adjectives more specifically reveals the attendant corollary to this mode of thought, which is the inherent separateness of categories within an immutable order dictated by an elusive higher (perhaps divine) power. In relation to gender, the narrator at one point speaks of the "distinct roles that the sexes were intended to occupy" and "the different natures and capacities of men and women" (33; emphasis added). ${ }^{3}$ Such essentialist notions of separateness also characterize his attitude toward race. While the condescending narrator is by no means as hostile to people of African descent as some of his contemporaries (hence the "relative open-mindedness" Ledent points out ["Determinism" 79]), his racial intolerance most acutely manifests itself in his disapproval of miscegenation. Whereas the narrator merely "describes blacks through the language and attitudes of the time and place he inhabits" (Birat 61), his characterization of Barber's "irregular," "strangely coloured" mixed-race children (Phillips, Foreigners 43, 17) invites a more disquieting reading. On two occasions, the narrator refers to the daughter of Barber and his white wife Betsy as a "mongrel" (37, 54), a chiefly depreciative term designating a person of mixed descent but which, importantly, also applies to dogs of undefinable breed. Here Phillips clearly lurks within his narrator's discourse, for the writer sets up 
a polyphonic resonance that simply cannot be ignored, as other examples confirm. Elsewhere, the child is called a "cub" (36), a term typically applied to animals; in yet another passage, the daughter is "curled across her [mother's] lap like a slumbering animal' (43; emphasis added). Moreover, the young girl is most often assigned the pronoun "it," even after the narrator has "determined [the child] to be female" (17). Thus, the "zoological terms" that colonizers so often used to "dehumaniz[e] the native" (Fanon 32, 33) are here employed to express disapproval of the "aberrant union" (Phillips, Foreigners 40) between Francis and his wife. No wonder, then, that the narrator has "begun to contemplate some involvement in . . Mr Granville Sharp's scheme for resettling blacks on the west coast of Africa"-a supposedly "philanthropic" project, which, conveniently, happens to put black people at a safe geographical distance from white English society (14).

The narrator's obsession with different forms of compartmentalization, I argue, betrays a larger urge for control that mirrors the totalizing impulse at the heart of colonial historiography. This makes "Dr Johnson's Watch" as much about the recounting of black history-and the reception of these accounts — as about the figure of Barber himself. ${ }^{4}$ I will develop this assertion by, once again, following the trail of the narrator's adjectives. However, my comments on this linguistic feature will acquire significance only when viewed within a larger theoretical framework articulated around the notions of modality and point of view in narrative fiction. This stylistic theory, devised by Paul Simpson, will allow me to compare the techniques used in "Dr Johnson's Watch" with those displayed in the second section of Foreigners, "Made in Wales."

Simpson's theory (46-85) rests on the basic assumption that "[m]uch of the 'feel' of [a] text is attributable to the type of point of view it exhibits" (46). Central to his model is the concept of "modality," a term that, as I briefly suggested above, refers to the grammatical meansincluding modal auxiliaries and evaluative adjectives — that indicate "a speaker's attitude towards, or opinion about, the truth of a proposition" and, more generally, his or her "attitude towards the situation or event described by a sentence" (47). Building on this key role of modality, Simpson proposes a distinction between what he calls "category A" and 
"category B" narratives, which are accounts respectively told in the first and third person $(55) .^{5}$

"Category A" narratives, Simpson continues, "can be subdivided further on the basis of three broad patterns of modality, referred to as positive, negative and neutral" (55; emphasis in original). "A positive" narratives (A+ve narratives for short) are thus called because of their "positive shading": they are "co-operatively oriented towards the reader" (56). Typically, they abound in "generic sentences which possess universal or timeless reference" (57), verbs of feelings, evaluative adjectives and adverbs, so-called "deontic" modal elements (which foreground duties and obligations, such as the auxiliaries "must" and "may") and "boulomaic" modal elements (that is, words expressive of desire, such as the verbs "hope" or "wish"). Conversely, other features expressive of modality tend to be rare in A+ve narratives. These include "epistemic" elements (which are words concerned with the speaker's [lack of] confidence in the proposition expressed, including adverbs such as "perhaps" or "possibly," and the auxiliaries "may" and "must" when used to express probability) and elements of "perception" modality (that is, structures similar to "It is clear/evident that" or perception adverbs such as "clearly" and "evidently"). ${ }^{6}$

At the other end of the modal spectrum are "A negative" (A-ve) narratives. These are expressive of "bewilderment and estrangement" and exhibit precisely those features of modality that are suppressed in A+ve narratives; for instance, epistemic modal auxiliaries, lexical verbs such as "suppose" or "assume," and perception adverbs are common (Simpson 58). A-ve narratives also tend to exhibit "comparative structures which have some basis in human perception"-for example, "it looked as if," "it seemed," and "it appeared to be" (58). The last type of "category A" narrative, "A neutral," is so named because it does not exhibit narratorial modality: the narrator withholds judgments on events and characters and tells the story only through categorical assertions (60). This absence of modality gives "A neutral” texts a "flat, almost 'journalistic' feel” (61).

"Category B," or third-person, narratives can similarly be subdivided according to their positive, negative, or neutral shading but with the added difficulty that these texts may either be "related from a position 
outside the consciousness of any of the characters," or "mediated through the consciousness of a particular character" (62). On the basis of this distinction, Simpson proposes an additional division between two types of $B$ narratives: those "in Narratorial mode" $-\mathrm{B}(\mathrm{N})$ for short-and those "in Reflector mode" — which he abbreviates to B(R). ${ }^{7}$

These are the theoretical foundations of a model whose general spirit may be summarized as follows: narrators and/or focalizers of fictional accounts may be assertive, moralizing, and judgmental (positive shading), unsure and bewildered (negative shading), or impersonal and seemingly objective (neutral shading). Of course, as Dan McIntyre points out, "no text is likely to exhibit one type of narration alone" (29), but this need not be considered a weakness of Simpson's model. On the contrary, his categories provide a theoretical basis that enables scholars to "look at the effects generated by changes in narration, and to look particularly at how specific points of view effects are created" (McIntyre 29; emphasis in original).

Some critics of Foreigners have already started to follow the avenues of research that McIntyre points out. Analyzing point of view in "Dr Johnson's Watch," Kathie Birat observes that "[the narrator's] discourse is marked by a liberal use of modals, the conditional tense and verbs implying hesitation" (61), but that " $\mathrm{t}]$ he marks of hesitation in his discourse disappear as the narrator gradually evokes the reactions of the young Barber" when the latter's life story is recounted (62). This remark echoes Pirker's statement that the narrator first "overtly reports and comments" on the figure of Barber (for instance, by using introductory clauses such as "As far as I could ascertain") before "assum[ing] a covert position" and rendering "impressions of the experiences of Barber, Johnson and diverse other figures . . via internal focalisation" (211). Using Simpson's terminology, I would say that the opening section of Foreigners starts in A-ve mode when conveying the narrator's initial impressions of Francis Barber and then ventures into $\mathrm{B}(\mathrm{R})$ territory when the narrator is no longer directly involved in the action and focuses on Barber and Johnson's relationship.

The recourse to Simpson's theoretical model allows for more than simple paraphrasing of Birat's and Pirker's remarks. While the opening 
pages of "Dr Johnson's Watch" indeed exhibit the markers of hesitation noted by these two critics (along with features of perception modality, also typical of A-ve narratives), several other linguistic elements run counter to Simpson's predictions for A-ve accounts, indicating that the narrator is perhaps not as hesitant as one might initially suppose. Chief among these elements is the heavy use of evaluative adjectives. To cite a few examples, the narrator speaks of "the modest confines of Dr Johnson's house" (Phillips, Foreigners 3; emphasis added), of Barber's "virtuous affection" for his master (6; emphasis added), or of the "elegant monument to William Shakespeare" in Westminster Abbey (9; emphasis added). Even many of those adjectives that may semantically be classified as "descriptive" smack of evaluation when considered from a pragmatic (that is, context-based) perspective. This is the case of the terms referring to Barber's blackness discussed above, whose oldfashioned associations and accumulation account for their ideological connotations. Another striking example is the narrator's reflection that he (the narrator) "should be putting [his] educated mind to better use" (9; emphasis added) — a statement that, undoubtedly, does more than merely point to the objective fact that the man has received a formal education.

The clash between, on the one hand, the many modal markers of hesitation in the narrator's discourse and, on the other, his more assertive use of evaluative adjectives (particularly when used in attributive position) leads to a more significant finding. Observing Barber sitting alone at Johnson's funeral, the narrator first states, in typical A-ve style, that the servant "appeared to be genuinely consumed with grief" (Phillips, Foreigners 10; emphasis added). In other words, the narrator relies on his visual perceptions to posit that Barber is in a state of emotional distress and sincere bereavement. Any sense of tentativeness, however, disappears when later in the paragraph Barber is simply called "the sad negro" (10) and "this poor man" (10-11). In such phrases, the black man's sadness or misfortune is no longer asserted (that is, featured as the main proposition of the sentence, and therefore accessible to debate) but it is assumed, located inside grammatical structures whose content is cognitively more difficult to call into question-or, in more 
precise linguistic terms, Barber's sadness and misfortune is presupposed. Hence, the narrator's initial, tentative and openly subjective impression of Barber's state of mind becomes ideologically encoded into the narrative through the use of emotive adjectives placed in attributive position. Such textual manipulations are easily overlooked since they coexist with typically A-ve elements that persist throughout the narrator's account of Johnson's funeral. For instance, in the next paragraph, the narrator again tentatively interprets Barber's attitude when he describes Barber as "seemingly reluctant to rise to his feet" (11; emphasis added).

While shifts from assertion to assumption may be discreet, woven together as they are with a plethora of more hesitant statements, they are not as trivial as they might appear. Even before discovering the full story behind Barber's misfortunes, which lead the Jamaican to spend his final days in an overcrowded infirmary, the narrator speaks of the "careless Barber" who "managed to fully deplete the capital" bequeathed to him by Dr. Johnson (Phillips, Foreigners 21; emphasis added). In other words, the narrator presupposes Barber's responsibility in his own demise. Later in the narrative, a far more nuanced account emerges from the story told by Barber's wife, who explains that weaknesses in her husband's personality, racial prejudice in England, and some individuals' ill-intentioned behavior all contributed to his ruin (53-54). This intricate picture is completed by Barber himself when he states that, during the course of his life with the generous Dr. Johnson, "the limits of his abilities" were continually "blurred by kindness, dependence, and [his] own indolence" (58). Disregarding these complexities, the narrator subsequently mentions that Barber is a "pathetic negro" (61). This is yet another strategically placed attributive adjective that presupposes, and therefore presents as evident, the former servant's "pitiful" state (59). The attentive critic will of course notice that the narrator "fails . . to understand [the] irony" behind Barber's words (Ledent, "Determinism" 79), but, as the Jamaican's helplessness is ideologically encoded into the narrative account through the attributive position of "pathetic" and "pitiful," the reader is more likely to internalize this view of the black man as historically accurate. Revealingly, Pirker includes among the "known facts" of Barber's life the idea that, after Johnson's death, "Barber 
is unable to stand on his own feet" (196; emphasis added). In other words, the scholar seems to unwittingly lean toward an infantilization of the servant akin to the narrator's own.

Such examples support my suggestion that point of view and modality, here embodied in the use of evaluative adjectives, contribute to the construction and transmission of the narrator's skewed view of history, compartmentalized along the lines of black vs. white, upper class vs. lower class, and, as has now become clear, dignified vs. pitiable. These examples betray the narrator's worldview, but they also epitomize how subjective renderings of history are constructed, transmitted, and sometimes made to appear commonplace. In the early stages of the story, the narrator's ideological rigidity is limply camouflaged by an overabundance of linguistic expressions indicating tentativeness, and by affectedly modest statements about the quality and authority of his account (Phillips, Foreigners 3). Eventually, however, his conversation with Barber leads him to draw a more authoritative conclusion: "[T]he black should have left our country and journeyed back to Jamaica or to Africa with Mr Sharp's expedition. In fact, all ebony personages should do so for I was now convinced that English air is clearly not suitable for negro lungs" (59). This short passage displays several features typical of A+ve narratives: the assertion that Barber "should" have left England is an expression of deontic modality, while the fact that "all ebony personages" should do so is a generic assertion. The epistemic and perception modalities that characterize the narrator's speech are still present; nevertheless, both occurrences in this passage ("convinced" and "clearly") are indicative of confidence rather than self-doubt. It is striking that this self-assured pronouncement comes after the narrator has been presented with the supposed "evidence" of Barber's demisethe narrator's entire account, one might say, takes the form of a dubious scientific demonstration that only reinforces his initial prejudices.

Importantly, the narrator remains entirely unaware of the thwarted logic of his reasoning. At the end of his story, he concludes that "[a] biographical sketch [of Barber] in the Gentlemen's Magazine would most likely be met with the same combination of fascination and disdain that had blighted" the servant's life (61). In light of the observations I 
make above, the irony is unmistakable, since the mixture of "fascination and disdain" seemingly deplored by the narrator also characterizes his own attitude toward the Jamaican. This ironic statement also acts as a cautionary remark to the contemporary reader. Once again, this interpretation is made possible by the recognition that this narrative statement is double-voiced: this is a clear case in which the "implied author communicates with the reader 'over the head', as it were, of the narrator," who is himself "unaware of the ironies generated by his discourse" (Black 116). Thus, Phillips hides within the text to undermine the supposedly "generous" (Foreigners 6) nature of his narrator's tale and, perhaps, to alert readers to their own well-meaning but potentially problematic negotiation of Barber's story. The narrator's final act supports this reading: he allegedly altruistically gifts to Barber's wife the watch that Dr. Johnson once left to his servant-a gesture that, very much like the narrator's account, perpetuates the muddled confusion between benevolence and paternalism that still characterizes white hegemonic discourses today.

A factor that I left aside in the above analysis is the narrator's use of internal focalization in the passage describing the relationship between Johnson and Barber. On the surface, this technique merely seems to confirm that the storyteller shamelessly appropriates-or, indeed, colonizes - the inner lives of his biographical subjects by adopting perspectives that can only be based on imagined reconstructions of the two men's inaccessible intimate thoughts. Alternatively, one might argue that such polyphonic passages reveal a genuinely empathetic tendency on the narrator's part to identify not only with white Dr. Johnson but also with black Francis Barber, whose feelings are given expression in this section of the text. This no doubt contributes to the narrator's ambiguity as a well-meaning but problematic figure.

At first sight, such a complex use of voice and point of view appears to neatly contrast with the approach adopted in "Made in Wales," the second section of Foreigners that retraces the rise and fall of boxer Randolph Turpin in the mid-twentieth century. Ledent describes this story, supposedly "told from the outside" (Ledent, "'Only Connect" 188), as "a factual account" (Ledent, "Determinism" 80), and Birat calls 
it a "straightforward non-fictional text" (59). Another commentator, using less generous but particularly revealing terms, states that the Turpin section "reads like an extended Wikipedia entry" (Goodheart). These impressions of the story's seemingly neutral, seemingly external point of view can be attributed to the "rather dry and journalistic style" that Phillips adopts (Ledent, "Determinism" 80). As the writer has confirmed, he consciously attempted to "fashion something akin to sports reportage" in recounting Turpin's life (“'Only Connect”" 189). Based on these comments, as well as on my own initial impressions, I started out my stylistic analysis of "Made in Wales" with the hypothesis that the text would largely conform to what Simpson identifies as a category $\mathrm{B}(\mathrm{N})$ neutral narrative-that is, a third-person account adopting an external perspective and containing few expressions of modality. But the text disproves these theoretical presumptions. Had the Turpin section really been a Wikipedia entry, it would have been flagged for seriously breaching the website's policy of both neutrality and verifiability.

Indeed, even though "Made in Wales" mentions many names, dates, and addresses - all of which reinforce the impression that facts are reported in a neutral and descriptive way-the narrative is far from straightforward in its use of modality and focalization. On the modal plane, the first part of the section in particular contains general statements typical not of B neutral but of assertive B+ve narratives, such as "The British have always held their prize fighters in high esteem" (Phillips, Foreigners 76) and "Everybody in Britain knew that Turpin carried a potential knockout punch in both hands" (127). The latter statement, especially, is obviously not to be understood literally but as a sweeping declaration that reinforces Turpin's immense popularity in Britain at the height of his sporting career. While one might argue that such generalizations appear in even the most "objective" attempts at historiography, other features in the narrative are more revealingly indicative of a "subjective" B+ve stance. Most notably, the narrator repeatedly uses the boulomaic adverb "unfortunately" $(106,123,164)$ to deplore the course of Turpin's life and the adverb "sadly" $(90,148)$ in reference to the man's difficult family situation. Such expressions of 
modality testify to the narrator's allegiance to the boxer-a stance akin to that of a sports commentator championing a local hero against the opposition. ${ }^{8}$ These details indicate that, contrary to widely held critical beliefs, something is being done with point of view in "Made in Wales"; suffice it now to establish precisely what and why. I will attempt to do so by isolating two precise features in this unusual reportage, namely the narrator's temporal position and his use of focalization.

First, an examination of point of view in the story shows that the narrator regularly shifts his temporal position in relation to his subject. Indeed, the narrative opens with an account of Turpin's arrival in London " $[\mathrm{o}] \mathrm{n}$ the morning of 9 July, 1951" and then states that "today there was something auspicious" about the boxer (Phillips, Foreigners 63; emphasis added). The latter passage has a sense of immediacy that suggests the anticipation presumably felt by the participants in, and observers of, the events being reported. Later in the same paragraph, the narrator describes Turpin's promoter, Jack Solomons, as a man "who, in the parlance of the times, liked to talk fast and plenty" (64; emphasis added). This expression clearly signals a sense of temporal distance from the events recounted. However, the narrator adopts similar "parlance of the times" throughout the story, as he constantly describes the mixedrace Turpin as "coloured," a term now considered dated, or indeed offensive. These racial references are-just like the use of the adverb "today" - suggestive of polyphony, because the text features one voice located at the time when the events unfold and one at the time when the story is narrated. To give but one example of the former case, the narrator's assertion that manager "George Middleton . . . foolishly overmatched the promising coloured fighter" (69)-i.e., young Randolph Turpin—with Sugar Ray Robinson clearly ventriloquizes the opinions of skeptical observers before the mixed-race boxer's victory over the American champion. As in "Dr Johnson's Watch," the dated racially related vocabulary used in "Made in Wales" discreetly encodes prejudice into the narrative and hence indirectly hints at the racist ideologies that shaped the life of its protagonist. However, polyphonic strategies do not operate in the same way in the two stories. In the opening section of Foreigners, the technique works covertly, since narrative authority 
is assigned to an imaginary contemporary of Francis Barber, and the reader must retrieve instances of overlexicalization and irony through pragmatic interpretation. In "Made in Wales," on the other hand, double-voicedness is - despite critics' impressions of factuality-far more perceptible, as in the following passage:

Many believed that being from the only coloured family in the town obviously informed the boy's [young Turpin's] delinquency. It did not occur to them that being the only coloured family in town meant that the Turpins, Randy included, had to be able to take care of themselves, and sometimes get their retaliation in first. In the thirties, most British people were unfamiliar with the novelty of living among people of another race, but given the evidence of the Turpin family, the novelty of living with coloured people was something that a number of the more narrow-minded townsfolk of Leamington Spa had concluded they could do without. (94; emphasis in original)

The excerpt starts by reporting the opinions of "many" inhabitants of Leamington Spa, whose voices can be discerned in the presence of the adjective "coloured" and, even more visibly, of the perception adverb "obviously." The narrator then takes hold of the textual reins by detailing what "did not occur to" the people of the town, offering an alternative interpretation of the reasons for Turpin's "delinquency." This analysis of the situation turns out to be retrospective, as the adverbial of time "[i]n the thirties" seals the narrator's sense of temporal distance from the events; at the end of the passage, the adjective "narrowminded" unambiguously reveals his precise stance on the matter. All the while, white Leamingtonian voices continue to resurface in the text: for example, the supposed "evidence" of black delinquency in the Turpin family reflects these people's opinions, in addition to expressing the narrator's doubtful attitude toward the alleged proof. In sum, the narrative alternatively borrows the voices of those involved in the events and distances itself from them, an oscillation that is also reproduced in temporal terms. Importantly, these techniques offer a first glimpse into how the account approaches historiography-as a 
seemingly coherent narrative that in fact emerges from the constant confrontation between voices and temporal planes. Whereas the neat cohesion of the text may indeed give the impression that one is confronted with "a paratactic structure-and then, and then, and then" (Yelin, "Migrant Subjects"), "Made in Wales" bears far more traces of the type of polyphony usually found in Phillips' texts than may initially appear to be the case.

The second feature I mention above, the use of focalization, confirms this observation. The narrative is by no means always "told from the outside" (Ledent, "'Only Connect” 188); rather, the narrator's temporal oscillation finds a striking parallel in his repeated incursion into the bodies and minds of his protagonists. This internal focalization is evidenced by the recurrent recourse to verbs and expressions denotative of cognitive and emotional states: Turpin's mother "gathered her wits about her," "sensed," "worried," "knew" (Phillips, Foreigners 85); George Middleton "was alarmed," "was unconvinced" (123), "had little faith" (125); Turpin "knew" (83), "was aware" (92), "felt at ease" (102), "realized" (123), and so on. ${ }^{9}$ Interestingly, even as the narrator assigns his protagonists specific states of mind and verbs of feelings, thereby venturing into what Simpson calls $B(R)+$ ve mode (a third-person narrative in focalizer mode in which the feelings of the focalizer are reported on), he also moves back to the estranged, external perspective of the $\mathrm{B}(\mathrm{N})$-ve mode on a regular basis. This is particularly noticeable in the passage recounting the legendary fight between Randolph Turpin and Sugar Ray Robinson, in which the American's behavior is, initially, mostly interpreted from the outside using the conjunction "as though," which Boris Uspensky identifies as a term "of estrangement" (85). Thus, Robinson "bob[s] and weave[s] as though eager to let everybody know that he was ready for business" and "bang[s] his gloves together as though eager to get the proceedings over and done with" (81; emphasis added). However, the focalization then becomes internal: the American "wonder[s] if the Limey was yellow" (81; emphasis added). Similarly, Turpin initially "[sits] slumped on his stool as though awaiting his fate" but then gets up, "knowing that there was now no turning back" (81, emphasis added). 
Such frequent changes in point of view, I argue, account for more than localized stylistic effects in climactic scenes - they are part and parcel of the multifaceted narrative strategy of "Made in Wales." Indeed, the narrator at times confidently recounts the story of Turpin by assigning the protagonist specific states of mind, but at other times he struggles to impose an interpretation on the events. Most notably, when Turpin, after his victory over Robinson, is invited to a reception in his honor at the Leamington Spa Town Hall, the narrator first reports, in $\mathrm{B}(\mathrm{R})+\mathrm{ve}$ mode, that the "overwhelming adulation" of the cheering fans "brought a lump to Turpin's throat” (Phillips, Foreigners 86-87). Only a few sentences later, a radically different $\mathrm{B}(\mathrm{N})$-ve mode prevails when, describing the photos of Turpin from the event, the narrator states that the young man "appears to be a little confused. In almost every photograph he seems to be avoiding full eye contact with the camera as though hiding from somebody, or himself" (87; emphasis added). More than simply including a few token markers of hesitation, this excerpt casts the spotlight on the act of interpretation involved in the reconstruction of a narrative based on archival material. I posit that such passages, which contrast with those that unambiguously identify Turpin's feelings and sensations, purposefully problematize the process of historiographical encoding made to appear so self-evident by the narrator of "Dr Johnson's Watch.”

As "Made in Wales" progresses, this tension between factual exposition and tentative interpretation becomes more palpable, as the authority of the $\mathrm{B}(\mathrm{R})$ +ve mode and the hesitancy of the $\mathrm{B}(\mathrm{N})$-ve mode increasingly clash. For instance, at a late stage in the story, the narrator reports that Turpin, forced to earn a living after his boxing career, persists in taking part in wrestling matches "despite his own reservations and his evident discomfort" (Phillips, Foreigners 145). While the mention of the former champion's "reservations" suggests unmediated access to (or at least unwavering labelling of) his state of mind, his "evident discomfort" (emphasis added) includes a marker of perception modality signaling that the narrator is making an interpretation from an external vantage point. In another passage, the narrator states that Turpin's "anxiety over his debts was compounded by the frustration of knowing that . . to some extent, the present situation was entirely one of his own making" (149; 
emphasis added). Here, a modal collision occurs between the epistemic expression "to some extent" (which hedges the claim being made) and the amplifier "entirely" (which, conversely, intensifies the message of the clause). Extending the musical metaphor of polyphony, one might say that such clashes cause the narrative to become increasingly dissonant. In this way, I argue, Phillips, who had been hiding within the text, slowly comes into visibility in Foreigners, even before "an 'I' narrator-obviously Caryl Phillips himself" makes an appearance at the end of "Made in Wales," "decoding [Turpin's] life story and approaching it from a more intimate angle" (Ledent, "Determinism" 80).

Phillips' eventual appearance as a homodiegetic narrator (that is, one who is a character in his own tale) marks an attempt to reconcile the two discursive modes present within the Turpin narrative - on the one hand, the factual, non-fictional discourse of journalism and, on the other, the fictional genre characterized by conjectural liberties. After listening to the testimonies of two of Turpin's daughters, Phillips concludes:

Turpin's inner turmoil towards the end cannot have been simply fuelled by anxieties over a lack of money, and anger and frustration at having allowed himself to be used by people. There must have been a deeper, and in the end a far more destructive, hurt. . . . He lived with this hurt for many years . . . and the great mystery is how he survived for so long. (164)

The beginning of this passage features the epistemic modals "cannot" and "must," both of which mark strong commitment to the factuality of the propositions expressed but do not indicate an omniscient point of view. These markers of modality, however, disappear in the following sentence, in which Phillips plainly states that Turpin "lived with this hurt for many years." Yet this extrapolation is then immediately followed by the mention of a "great mystery" that remains unresolved. Phillips, in other words, once more adopts a point of view outside Turpin's consciousness and ultimately leaves his narrative at the crossroads of imagination and fact, fiction and non-fiction.

If the different sections of Foreigners are indeed "written in distinctive styles expressive of the individuality of each . . . of [Phillips'] protago- 
nists" (Ledent, "Dignity" 73), then these styles also allow the implied author to couch his reflections on the problematic construction of historiographical discourse in radically different ways. Rather strikingly, the propensity to increasingly foreground the tension between historical facts and narratorial interpretation in "Made in Wales" (either by introducing dissonances within the text or by having the narrator step into the story to ponder on these discrepancies) contrasts with the growing tendency toward authoritativeness and generalization at the end of "Dr Johnson's Watch," at least where matters of race are concerned (recall the statement that "all ebony personages" "should . . . [journey] back to Jamaica or to Africa" [Phillips, Foreigners 59]). In this sense, the first two sections of Foreigners, despite their protagonists' common downfall, can be regarded as structural mirror images of each other. On the one hand, the Francis Barber narrative is largely left in the hands of a well-meaning but ultimately patronizing narrator, which works to reinforce the idea that the former servant, as he admits himself, "lack[s] dignity" (58). On the other, the Turpin section, without glossing over its protagonist's tragic fate, reconstructs the boxer's life in all its complexity and eventually leaves the reader with the idea, articulated by Turpin's daughter Charmaine, that this particular Englishman "always had dignity" (163). In typical Phillipsian fashion, it befalls the reader to decode the workings of the sections' polyphonic strategies and to determine what the stories have to say about the artificial nature of historiographical discourse. In each of these cases, this can be done by seeking out the author's hiding places within the text. In "Dr Johnson's Watch," Barber's dignity, of which the narrator largely robs him, can be restored, but only through a critical reading of the text; one must, in other words, become fully aware of the biased ideologies that dominate the narrator's account to expose the attitudes that they conceal. The second section demands a similarly sustained engagement, but, conversely, the text openly and increasingly foregrounds the difficulty of imposing interpretations on so-called historical "facts."

If "Dr Johnson's Watch" and "Made in Wales" are structural mirrors of each other, then the third section of Foreigners, "Northern Lights," might be a shattered version of these looking-glasses. Undoubtedly the most fragmented section of the three, the story of David Oluwale "is 
told in a totally unpredictable way through a medley of voices with many different tones" (Ledent, "Determinism" 82). This sophisticated polyphonic assemblage demands a far more elaborate treatment than I can give in this article. The extent to which the absence of this analysis will be perceived as a shortcoming of this essay may, paradoxically, be a measure of the critical potential of its methodology: if the reader is left wanting to know more, then perhaps the stylistic approach adopted in these pages does have something to contribute to the critical evaluation of Phillips' texts. If the opposite impression prevails, then I invite readers to reflect on the limits of the methodological exercise proposed here. This suggestion is not as self-defeating as it may appear, for one of the aims of stylistics is precisely to foster reflexivity on readerly procedures - all the while keeping in mind how one might elucidate the artistic messages that a writer such as Phillips so convincingly, and at times so elusively, conveys.

\section{Notes}

1 On the intertextual link between Anne Frank and Phillips' Higher Ground and The Nature of Blood, see Ledent's Caryl Phillips (68 and 155-59) and Craps (169-71); on the relationship between Equiano and A Distant Shore, see Ledent's "Family and Identity" (71). Gillet (323-24) also discusses the latter link in more detail and establishes parallels between $A$ Distant Shore and Cambridge based on their common use of Equiano's narrative.

2 This reference work goes so far as describing the word "negro" as the "standard designation" for black people until the middle of the twentieth century ("Negro, n. and adj.")—and indeed, the term was used without racist undertones by a long line of twentieth-century black writers, from Langston Hughes to James Baldwin.

3 That this compartmentalization betrays an obsession with order is also suggested by the narrator's comment that one must "rul[e] these trifling creatures [i.e., women] with benevolent determination" lest "things . . . fall out of their natural order" (Phillips, Foreigners 33).

4 This assertion somewhat echoes Birat's statement that the "invented voice" that tells Barber's story, "like all first-person narrators, reveals as much about himself in his telling of Francis Barber's life as he does about Barber" (61). However, my claim differs from Birat's in its perception of the narrator's account not as a biography composed by a man who holds prejudices typical of his times but as a text used by Phillips to comment on historiography itself. Put differently, I argue that the encoding of ideologies into the narrative illuminates how historical "facts" are textually constructed. 
5 These categories broadly correspond to what Genette has famously called "homodiegetic" and "heterodiegetic" accounts: on the one hand, narratives where the narrator is a character in the situations and events recounted, and on the other, those where he or she is not. For clear and concise definitions of narratological terms, see Prince.

6 Perception modality may be considered a sub-category of epistemic modality, since it reflects how "the degree of commitment to the truth of a proposition is predicated on some reference to human perception" (Simpson 50).

7 The "reflector" is the "holder of point of view," a narrative agent more commonly called the "focalizer" (Prince 82).

8 The narrator of "Dr Johnson's Watch" also uses boulomaic adverbs, showing a marked preference for "sadly" $(27,37,46,49,51)$ over "unfortunately" (1), though the adjectives "sad" and "unfortunate" recur in equal measure. Along with the evaluative adjectives that I discussed above, these adverbs suggest that the "negative" modal shading of the opening section is a front hiding a more assertive subjectivity.

9 The extent to which these references to the protagonists' states of mind are derived from historical documents (such as interviews or other journalistic reports) does not bear any direct relevance to the argument, since in all cases conjecture is at work-whether it takes the form of assigning authority to a historical source or attributing motivations to the people involved based on actions that they performed during their lifetime.

\section{Works Cited}

Bakhtin, M. M. The Dialogic Imagination: Four Essays. Trans. Caryl Emerson and Michael Holquist. Austin: U of Texas P, 1981. Print.

—. Problems of Dostoevsky's Poetics. Trans. Caryl Emerson. Minneapolis: U of Minnesota P, 1984. Print.

Bal, Mieke. "Critique of Voice: The Open Score of Her Face." Analysieren als Deuten: Wolf Schmid zum 60. Geburtstag. Ed. Lazar Fleishman, Christine Gölz, and Aage A. Hansen-Löve. Hamburg: Hamburg UP, 2004. 31-51. Print.

Birat, Kathie. "Creative Biography': Fiction and Non-Fiction in Caryl Phillips's Foreigners: Three English Lives." Commonwealth: Essays and Studies 36.1 (2013): 57-67. Print.

Black, Elizabeth. Pragmatic Stylistics. Edinburgh: Edinburgh UP, 2006. Print.

Craps, Stef. "Linking Legacies of Loss: Traumatic Histories and Cross-Cultural Empathy in Caryl Phillips's Higher Ground and The Nature of Blood." Caryl Phillips: Writing in the Key of Life. Ed. Bénédicte Ledent and Daria Tunca. Amsterdam: Rodopi, 2012. 155-73. Print.

Eckstein, Lars. Re-Membering the Black Atlantic: On the Poetics and Politics of Literary Memory. Amsterdam: Rodopi, 2006. Print. 
Equiano, Olaudah. The Interesting Narrative of the Life of Olaudah Equiano, or Gustavus Vassa, The African, Written by Himself. 1789. The Interesting Narrative and Other Writings. Ed. Vincent Carretta. New York: Penguin, 1995. 1-236. Print.

Fanon, Frantz. The Wretched of the Earth. 1961. Trans. Constance Farrington. London: Penguin, 1967. Print.

Fowler, Roger. Linguistic Criticism. 2nd ed. Oxford: Opus, 1996. Print.

Frank, Anne. The Diary of a Young Girl. 1947. Trans. Susan Massotty. Harmondsworth: Penguin, 2000. Print.

Genette, Gérard. Narrative Discourse. Trans. Jane E. Lewin. Ithaca: Cornell UP, 1983. Print.

Gillet, Lucie. "Omnipresent and Everlasting Imperialism: Race and Gender Oppression in Caryl Phillips's Cambridge and A Distant Shore." Caryl Phillips: Writing in the Key of Life. Ed. Bénédicte Ledent and Daria Tunca. Amsterdam: Rodopi, 2012. 321-31. Print.

Goodheart, Adam. "The Outsiders." Rev. of Foreigners, by Caryl Phillips. New York Times 23 Dec. 2007. Web. 28 Apr. 2014.

Kuurola, Mirja. "Caryl Phillips's Cambridge: Discourses in the Past and Readers in the Present." Nordic Journal of English Studies 6.2 (2007): 129-44. Web. 28 Apr. 2014.

Ledent, Bénédicte. Caryl Phillips. Manchester: Manchester UP, 2002. Print.

—. "Caryl Phillips: The Dignity of the Examined Life." Routledge Companion to Anglophone Caribbean Literature. Ed. Michael A. Bucknor and Alison Donnell. Abingdon: Routledge, 2011. 72-77. Print.

. "Family and Identity in Caryl Phillips's Fiction, in Particular A Distant Shore." Commonwealth: Essays and Studies 29.2 (2007): 67-73. Print.

—. "'Look liberty in the face': Determinism and Free Will in Caryl Phillips's Foreigners: Three English Lives." Caryl Phillips: Writing in the Key of Life. Ed. Bénédicte Ledent and Daria Tunca. Amsterdam: Rodopi, 2012. 75-85. Print.

—. "'Only Connect': An Interview with Caryl Phillips on Foreigners." 2008. Conversations with Caryl Phillips. Ed. Renée T. Schatteman. Jackson: UP of Mississippi, 2009. 184-91. Print.

—. "Remembering Slavery: History as Roots in the Fiction of Caryl Phillips and Fred D'Aguiar." The Contact and the Culmination: Essays in Honour of Hena Maes-Jelinek. Ed. Marc Delrez and Ledent. Liège: L3, 1997. 271-80. Print.

. "Slavery Revisited through Vocal Kaleidoscopes: Polyphony in Novels by Fred D’Aguiar and Caryl Phillips." Revisiting Slave Narratives/Les avatars contemporains des récits d'esclaves. Ed. Judith Misrahi-Barak. Montpellier: Les Carnets du Cerpac, 2005. 281-93. Print.

- "Voyages into Otherness: Cambridge and Lucy." Kunapipi 14.2 (1992): 5363. Print.

McIntyre, Dan. Point of View in Plays. Amsterdam: Benjamins, 2006. Print. 
McLeod, John. “'Who are you calling a foreigner?': Caryl Phillips in Conversation with John McLeod." New Perspectives on the Black Atlantic: Definitions, Readings, Practices, Dialogues. Ed. Bénédicte Ledent and Pilar Cuder-Domínguez. Bern: Peter Lang, 2012. 275-94. Print.

"Negro, n. and adj." Oxford English Dictionary. 2003. Web. 28 Apr. 2014.

O'Callaghan, Evelyn. "Historical Fiction and Fictional History: Caryl Phillips's Cambridge." Journal of Commonwealth Literature. 29.2 (1993): 34-47. Print.

Phillips, Caryl. The Atlantic Sound. London: Faber, 2000. Print.

—. Cambridge. London: Bloomsbury, 1991. Print.

-. Colour Me English. London: Harvill, 2011. Print.

- Crossing the River. London: Bloomsbury, 1993. Print.

—. Dancing in the Dark. London: Secker, 2005. Print.

—. A Distant Shore. London: Secker, 2003. Print.

- The European Tribe. London: Faber, 1987. Print.

- Foreigners: Three English Lives. London: Harvill, 2007. Print.

- Higher Ground. London: Viking, 1989. Print.

- The Nature of Blood. London: Faber, 1997. Print.

—. A New World Order: Selected Essays. London: Secker, 2001. Print.

Pirker, Eva Ulrike. Narrative Projections of a Black British History. London: Routledge, 2011. Print.

Prince, Gerald. A Dictionary of Narratology. 2nd ed. Lincoln: U of Nebraska P, 2003. Print.

Rimmon-Kenan, Shlomith. Narrative Fiction: Contemporary Poetics. 2nd ed. Abingdon: Routledge, 2002. Print.

Schatteman, Renée T., ed. Conversations with Caryl Phillips. Jackson: UP of Mississippi, 2009. Print.

Short, Mick. Exploring the Language of Poems, Plays and Prose. Harlow: Pearson, 1996. Print.

Simpson, Paul. Language, Ideology and Point of View. Abingdon: Routledge, 1993. Print.

Taylor, Jeremy. "Man in Black." Caribbean Review of Books 21 (2010). Web. 28 Apr. 2014.

Uspensky, Boris. A Poetics of Composition: The Structure of the Artistic Text and Typology of a Compositional Form. Trans. Valentina Zavarin and Susan Wittig. Berkeley: U of California P, 1973. Print.

Yelin, Louise. "An Interview with Caryl Phillips." 1998. Conversations with Caryl Phillips. Ed. Renée T. Schatteman. Jackson: UP of Mississippi, 2009. 46-52. Print.

—_. "Migrant Subjects, Invisible Presences: Biography in the Writings of Caryl Phillips." ARIEL: A Review of International English Literature 48.3-4 (2017): 103-28.

- "Plural Selves: The Dispersion of the Autobiographical Subject in the Essays of Caryl Phillips." Caryl Phillips: Writing in the Key of Life. Ed. Bénédicte Ledent and Daria Tunca. Amsterdam: Rodopi, 2012. 57-73. Print. 